\title{
The Word (qara'a) (read) in the Holy Koran and pre- Islamic Poetry
}

\author{
Mahmoud Al Deeky \\ Al al-Bayt University, P.O.BOX 130040, Mafraq 25113, Jordan \\ E-mail:mmjbur@hotmail.com
}

Doi:10.7575/aiac.alls.v.7n.4p.124

URL: http://dx.doi.org/10.7575/aiac.alls.v.7n.4p.124
Received: 19/03/2016

Accepted: 01/06/2016

\begin{abstract}
This research deals with the verb "qara'a" (read) and with what is derived from or built on in Qur'an and pre Islam poetry. The research stems from the assumption that this item (read) did not appear in pre-Islam Arabic in the meaning agreed upon regarding the concept of reading a written text, and what is stated in the Qur'an regarding the use of this item (the verb read) is the development of the connotation of a language item related to a common Semitic origin. The connotation is linked with religious text, in the first place, in Aramaic, Syriac and Hebrew; its impact extended to Arabic with the revelation of Qur'an. The researcher concludes that the meanings and connotations stated in Arabic dictionaries of this language item are late, which Arab linguists tried to arbitrarily gear them to suit the new developed connotations.
\end{abstract}

Keywords: (qara'a) read, Qur'an, Pre-Islam poetry, connotative development, semantic, comparative studies

\section{Introduction}

The matter that the Arabs' knowledge before Islam about writing and reading has occupied a great deal of research and debate because of it is related to the illiteracy of Prophet Muhammad. This case has seized the attention of a number of researchers ${ }^{1}$, including Nasser al-Assad, and Jawad Ali. A lot of interest focused on the talk, which is evidenced in Islamic heritage sources regarding the first revelation revealed to the Prophet Muhammad. The first verse revealed to the prophet is (Read! In the Name of your Lord, Who has created (all that exists).Has created man from a clot (a piece of thick coagulated blood.Read! And your Lord is the Most Generous ,Who has taught (the writing) by the pen. Has taught man that which he knew not. (Surah Al-Alaq: 1-5). Arab Linguists did have doubts about the Arab origin of the word (qur'an قرآن). They unanimously agreed that qur'an is derived from the tri-consonantal root (أن (qara'a )read), and did not link it with any other relevant language item. They did not indicate that there is a relationship between this noun and any language other than Arabic. On the other hand, some orientalists, including Christoph Luxenberg, refuse that not any of the two verbs ( كتب write ) and ( I قرread) are of Arab origin. The reason , according to their opinion, is that the two verbs are linked to civilization, which is difficult for the two verbs to exist in desert environment that has no place in civilization ${ }^{2}$ depending on the Nöldeke' talk in his book "The History of the Qur'ān”.

In fact, the man lacks precision by depending on Nöldeke's talk. Nöldeke says it is probable that the verb (read) can not be belonging to what might be called the proto- Semitic language. It can be assumed that it has entered into Arabic from North Semitic languages, namely Syriac ${ }^{3}$. Moreover, the Arabic translation of the Nöldeke's talk was not accurate, where the translator says, "since a civilized word like ("qara'a" read) can not be an old Semitic word, and we

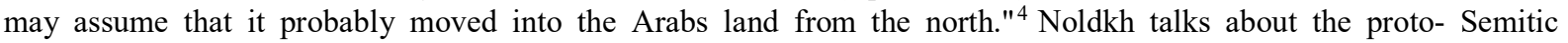
language, that language is supposed to had originated in a human evolution stage that had not known reading and writing yet, but people never disagree that the first alphabet was Semitic, where the civilization of Ugarit in the north of the Levant, the Southern Arabic writings in Yemen, the Northern language in the north of the Arabian Peninsula and the far parts of the Levant are very ancient, and where there is writing, there must be reading. I do not know how George Tamer, the translator of Nöldeke's book, suppose the transmission of this civilized verb ("qara'a" read) into

${ }^{1}$ For further information about the discussion of these opinions see:Afakher Alrazi, Mafateeh Alghaib (tafseer Alrazi), Beruit, Dar Alfiker :1981, Vol. 3, P. 148, and al-Raghib al-Asfahani, Mufradat Alfath Alqur'an madt(tamma) , PP.8687, and Masader alsher al-Jahili , P.45 and after, and Dr. Mohammad Abed al-Jabiri, al-Nabi al-Ummi >>and al-Umah al-Umiah.

Alitihad Newspaper, UAE dated 9/4/2006, and mohammad Shahrour , al-Kitab and al-Qura'n , qira'a muasera, Beruit, Dar al-Saqi:2010, P.139-143, Naser hamid Abu Zaid, Mafhouym al-Nass, Dirasat fi Aloumal-Qura'an, al-Haia alMasria lelkitab :1980, P.66, Mohammad al-Ahmadain , al-Woqouf ala alomia enda Arab al-Jahilia , Cairo, Markaz alHadara al-Arabia,:1999, P.90-95. 1

${ }^{2}$ Christoph Luxenberg, The Syro-Aramaic Reading of the Koran (German edition 2000, English translation 2007$)$ p 70

${ }^{3}$ Nöldeke , The History of the Qur'ān , pp1 \26-27

${ }^{4}$ see: Tarikh al-Qura'an, Noldeke, translated by George Tamer and others, Beruit print:2004, P.31 
Arabic from the north , depending on the supposition that the verb is not a type of verb belonging to the protorSemitics. The Syriac and Aramaic languages, He assumed that the verb moved from are Semitic languages. So, the conclusion of Nöldeke and his interpreter lack precision, and what is based on this is refused.

\section{Research assumptions}

The idea of this research is based on the assumption that ("qara'a, read) and the words derived from or built upon were not well known in North Arab language, Arabic of Pre- Islamic poetry, or what is known as the eloquent Arabic or what some people call literary Arabic in the sense that we know about reading from the advent of Islam until today. Thus, there are two possibilities in this sense of intensive emergence of this word in Arabic after the revelation of Qur'an.

The first possibility is the connotative development of a linguistic item that existed in Arabic.

The second possibility is that this word came into Arabic with the advent of Islam from North Semitic languages.

The research revolves around the following themes:

1. Identify the concept of reading precisely, namely silent reading and reading aloud.

2. Consider Arabic dictionaries, taking into account the fact that most of these concepts and connotations are relatively late.

3. consider the source of this item and its synonyms in the Nobel Qur'an, ( recite and intone "tala and rattala") and its connotation in the contexts in which they occurred. 4. Consider the occurrence of ("qara'a" read, and recite and intone "tala and rattala")) in pre-Islamic poetry.

5. consider the Semitic languages in order to find the origin of this word and determine its connotations and connotative development.

Any researcher studying the words of writing acts and its tools will come across rich material indicating that Arabs were not far from writing, and that writing was common among them. As for the degree of its popularity, it is a matter that need consideration ${ }^{5}$.

However, the striking point is the absence of three main verbs relating to writing ("qar'a")) read and ("darasa") studied and ("nasa $h$ " copied), the verbs that started to have intense presence with the revelation. What is meant by their absence here is that they were not used in pre-Islamic poetry in the meaning agreed upon regarding their connotations in Qur'an and in the sayings of the Messenger of Allah(PBUH ).

As the researcher is not able to accommodate all the three verbs in this study, he will concentrate on first verb (qara'a") read" and leave the other verbs for the future if he has the chance to do this later .

\section{3. ("qara'a" Read) in Arabic language dictionaries}

Usually, language dictionaries provide a number of meanings linked with the verb (read) and what is derived from or built on. It is noted that linguistics are confused regarding these meanings in their attempt to reconcile those meanings of this verb used by the Arabs before Islam and what became understood from them with the advent of Islam and after Islam . these meanings include:

1. Collection and compiling (al-Ta'lif). In al-Lisan dictionary, Ibn al-Athir says "the origin of this word means collection, and everything you have collected means you have read ${ }^{6}$. Qur'an is named so because it compiles a collection of stories, commands ,prohibitions ,promises, warnings, verses and chapters (Surahs) to each other ${ }^{7}$. Based on this meaning, the verse (And when We have recited it to you (O Muhammad ,through Gabriel, then you follow (the Qur'an's) recital. (Surah Al-Qiyamah, The Resurrection: 18), is interpreted. If we collect something from it, then we give it to you, take it, apply it and make it part of you . He cited the verse of poetry by Amer Bin Kalthoum to support this :

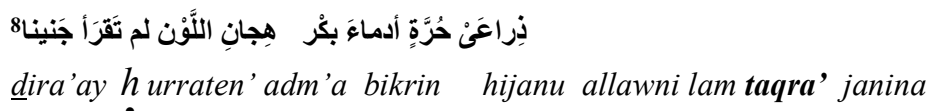

This verse means : she ( she camel) has never had a fetus in her womb , and the expression ("lam taqr'a") means it is used when describing a female that has never been pregnant ${ }^{9}$.

2. Read in the sense of recite, "I read the Qura'n means I read out part of it followed by another part until these parts come together as one part, giving the meaning of collection. ${ }^{10}$

\footnotetext{
${ }^{5}$ See: Jawad Ali, almufasal fi tareekh alarab qabl al-Islam , Baghdad, Baghdad University:1993,Part 8/248-250, and Naser al-Aldin al-Assad, Masader al-Shir al-Jahili, Cairo, Dar al-Ma'arif:1998, P.95, and Mahoud al_Deeky, Alfath alKitabeh fi Sher ma Qabl al-Islam, Majalat al-Adab, Vol. 12/2011, P.7-38

${ }^{6} \mathrm{Ibn}$ al-Athir, al-Nihaya fi Gharin al-Hadit wa al-Athar, edited by Taher Ahmad al-Zawi and Mahmoud Mohammad al-Tanahi, Beruit, al-Maktaba al-Ilmia :179, part 4 , bab alqaf ma' al-Ra'4/31.,and Ibn Mandour , al-Lisan, Beruit, Dar Sader(مأ) qara'a)1/127-132

${ }^{7}$ Majaz al-Quran, Abu Obaida Mu'amar bin al-Muthanna, edited by Mohammad Sazkeen, Cairo, Maktabat al-

${ }^{8}$ Diwan Amr Bin Kalthoum, P.68, the second part of the verse in many narrations, including she had never been pregnant (vergin), most of the narrations did not include the verb "taqr'a"; see footnote 18, appendix 18.

${ }^{9}$ see Majaz al-Qura'an , ibid, , and see al-Lisan"qar'a" (read), Beruit, Dar Sader, 1/127-132
} 
3. Read means recited and uttered ; the meaning of "I read the Koran" is "I uttered it all or recited it all".

Based on this meaning, the former verse of poetry by Amr Ibn Kulthum is cited; "she did not read embryo تقرأ جنينا 'lam taqr' janina " means the she camel had never had an embryo in her womb, that is had never been pregnant.

4. It means echoed and reinstated, and based on this some people interpreted the statement "yuqri'uka assalam بقرئك السلام" he sends you greetings ", and they said when he sends you greeting, he is asking you to echo and reinstate his greeting (slam). In the prophet saying "Abdullah Ibn Amer narrated that a man asked the Messenger of Allah( PBUH)

what Islam is good? the Prophet said " to give food and to greet the one you know or do not know ("taqr' assalam") ${ }^{12}$.

It is clear that the meaning in the Prophet's saying refers to greets and not reporting it as this word is often used.

5. It means reading the Qur'an in loud voice, and the meaning is found in the Prophet's saying narrated by Ibn Abbas he did not use to read aloud in prayers of Duher (noon) and Aser (after noon ) and he says in the end of the $h$ adi $t$ " and your Lord is never forgetful", This means that He did not use to read aloud in these two prayers or he did not hear himself while reading "13

6. He understands and lives a Hermitage life . as if reading entails understanding, and understanding entails living hermitage life. ${ }^{14}$

It is clear that all these uses are either late after Islam, or attempts by linguists and interpreters to reconcile the connotations of the word in the context contained in Qur'an or the Prophet's sayings (Hadith), and their reported connotations in pieces of evidence before Islam; linguists started to gear texts to make them agree with the connotations where the verb "read" (قرأ) appears in its new contexts. As for the sources of this linguistic item (قرأ in the Arabic of pre-Islamic period are as follows:

1. (alqr') and (alqari ), method and approach.

2. (Alqur time), and its plural is (quro'=times ), where the following verse is a supporting example $:{ }^{15}$

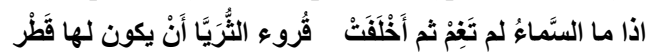

ida ma al-sma' lam tugim Kumma á́lafat quru' a h huryya an yakuna laha qatru

If the sky is not cloudy and it does not follow the astronomical time of Pleiades star that have to do with seasons and weather ( rain ..etc).

The menstrual periods(Quoro') contained in the Qur'an is not different in meaning from the meaning of the above verse ; (quru') of Pleiades star means its astronomical time.

And divorced women shall wait (as regards their marriage) for three menstrual periods. (Al-Baqarah: 228) This means the woman's menstrual periods, and this is similar to the verse of poetry by the poet al-A'sha :

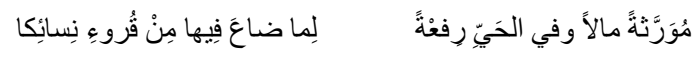

muwarrihatan malan wa fi alhayyi rife atan lima đa'a fiha men quru'i nisa'ika

She inherited money and had high status in her neighborhood where women spent their menstrual periods. And in the verse by al-A'sha : ${ }^{16}$

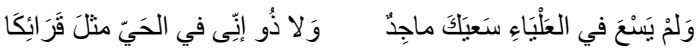

he said: No one of glorious people is similar to you seeking to reach the highest level of glory and non of people of

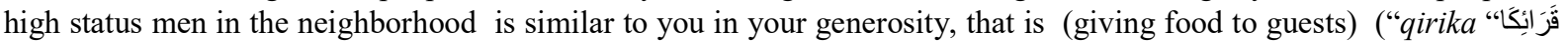
It is also easy to link this meaning with the former meaning in Amr Ibn Kulthum's verse of poetry :

ذِر اعَى حُرَّةٍ أدماءَ بَكْرَ هِجانِ اللَّوْن لم تَقَرَأ جَنينا

(the she camel like the color of soil and virgin did not have fetus in her embryo )

without enforcing meaning for the word ( $q a{ }^{\prime}$ ' $a$ )and link it to the meaning of reading in the Islamic sense which started to appear with the advent of Prophesy or before. It is also easy to link all connotations supplied by Arabuc language dictionaries to with time or timing, such as saying (aqra't al-reeh) means the wind blows on time, and

\footnotetext{
${ }^{10}$ Majaz al-Qur'an , ibid.

${ }^{11}$ See Ibn Mandour, al-Lisan, Beirut, bab Qar'a, P. 1/131

12 al-Bukhari, Sahih al-Bukhari, Beirut, Dar Ibn Kathir: 2002, Kitab al-Iman. Bab Ifshi' al-Salam Men al-Islam, P.17

${ }^{13} 1 \mathrm{Ibn}$ al_Athir, al-Nihyafi Gharib al-Hadith wa al-Athar, 4/31

${ }^{14}$ See:(tuqri'), al-Lisan, Ibid

15 See:(tuqri'), al-Lisan, Ibid

${ }^{16}$ Diwan al-A'sha, edited by Mohammad Hussein, Cairo, Maktabat al-Adab , JamamizD.T, P.91
} 
entered in its timely manner, and (alqari) means time , and the supporting example is the verse of poetry by Malik bin al-Harth al-Hudhali ${ }^{17}$

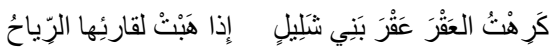

I hated the place called "al'aqr "where bani Shalil live, when winds blow .

A review of what is evidenced in dictionaries, books of interpretation, and the attempts to link new connotations that had emerged with the advent of prophecy, and the discussion mentioned in many sources, especially Sirat Ibn Ishaq on the beginning of the revelation regarding the verse (I can not read), are clearly poor attempts as the researcher can not rely upon them.

\section{Synonyms of (qara'a) read}

Two linguistic items appear in Qur'an where they are used to denote what is indicated by ("qara" read) namely, are recited and intoned (tala and rattala) respectively. Here, what deserves to look at is the derivatives ("tala/ yatlu, yatli") as the tense intoned)" (rattala) has clear connotation since the verb (rattala intone) is clear in connotation, and it is not a synonym of the verbs read and recited, but refers to a special type of special reading of the Qur'an as any intonation is necessarily reading, but not any reading is intonation. The utterance (" rattala " intoned ) is given to everything of good coordination.In Qur'an, it means the good coordination and arrangement of reading, so that reading will have impact in hearing and heart. ${ }^{18}$

tala/yatlu, yatli

The past tense and present tens (tala/ yatlu, yatli) respectively come in two forms (" tala/ yatlu, yatli" recited, and to recite ) the meanings of these words revolve around succession, as if something follows something that happened before it, and unite statement so (x) followed( y) means he (x) came after( $\mathrm{y})$ and followed him . Also, language dictionaries provide some metaphoric meanings for this word all of which are related to the meaning of succession; from this theme, al-taliyyah and al-tilawah mean the remains as they follow what took place before .As Bin Miqbil said in a verse of poetry: ${ }^{19}$

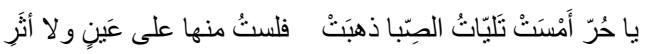

O free man, the rest of the soft gentle breeze wind (saba صبا) vanished and there no traces of them left. But the poet al- Akhtal gives special meaning to this word which I could not find in the works of others, and it is not related to the meaning of succession, but it means a good voice in singing, as indicated in the second part of the verse :The nice singing : ${ }^{20}$

صلت الجبين ، كأن رجع صهيله زجر المحاول ، أو غناء متال

According to the dictionary Lisan Alarab , " the Arabs call the person who sings while grazing his camels the intoning singer ( almatali ); and I recited Qur'an means I read it:, and in the Prophet's saying about the torment of the grave : " when the hypocrite is put in his grave, he will be asked about Mohammad (PBUH) and what he brought , he will say : I do not know, then it is said to him " you do not know and you did not recite Qur'an and you were not guided $^{21}$.

\section{5. (qara'a) and(tala) in the Qur'an}

Arabic Language dictionaries and books of interpretation indicate that reading means the right utterance of the word and letters, but reading Qur'an entails the following:

1. Listening and being silent (when the Qur'an is recited, listen to it, and be silent that you may receive mercy. Surah Al-A'raf: 204)

2. Following (And when We have recited it to you, then you follow, its (the Qur'an's) recital.

(Surah Al-Qiyamah Resurrection: 18). This verb has been stated in Qur'an 16 times, as follows:

First, reading the Qur'an

1.So when you want to recite the Qur'an, seek refuge with Allah from Shaytan (Satan), the outcast (the cursed one). (Surah An-Nahl:98)

2. And when you (Muhammad) recite the Qur'an, We put between you and those who believe not in the Hereafter, an invisible veil (or screen their hearts, so they hear or understand it not).( Surah Al-Isra': 45)

\footnotetext{
${ }^{17}$ Diwan al-Hathalin, Cairo, Dar al-Kutub al-Masria, Ahmed al-Zain, edition 2 , 1995 3/83 where it was included (qariha)

${ }^{18}$ see al-Lisan, (rattala)

${ }^{19}$ Ibn Faris, Maqis al-Lugha, , edited by Abd al-Salam Haroun, Damascus , Ithiad alkutab al-Arab :2002 , 1/322, and

the verse is in Diwan Ibn Miqbel, edited by Azza Hassan, Beirut, Dar al-Sharq al-Arabi:1995. P. 7

${ }^{20}$ It is not his diwan, this is what is included in al-1Lisan regarding (tala) and Maqais al-Lugha 1/322

${ }^{21}$ Sahih al-Bukhari, Kitab al-Janiz, Prophet Saying NO. 1374 , and fath al-Bari 3/232, al-Lisan, and al-Sihah, and alQamous al-Muheet, and al-Abbab , and Taj al-Arous (talya, talawa"recited recitation") ,
} 
3. And he had recited it unto them, they would not have believed in it. (Surah Ash-Shu'ara' :199) 4.) And (it is) a Qur'an which We have divided (into parts), in order that you might recite it to men at intervals. Surah Al-Isra':106)

5. He knows that you are unable to pray the whole night, so He has turned to you (in mercy). Surah AlMuzzammil: 20)

6. Yet others fighting in Allah's Cause. So recite as much of the Qur'an as may be easy (for you). Surah AlMuzzammil: 20)

7. and when We have recited it to you, then you follow it (the Qur'an's) recital. Surah Al-Qiyamah:18)

8. So, when the Qur'an is recited, listen to it, and be silent that you may receive mercy. Surah Al-A'raf:204 )

9. And when the Qur'an is recited to them, they fall not prostrate, Surah Al-Inshiqaq:21

It is clear that any of these verses does not refer to the reading of a written text, and they do not go beyond the concept of repetition, recurrence and making the receiver listen to the religious text. As for the verse (then ask those who are reading the Book [the Taurat (Torah) and the Injeel (Gospel)] before you.) Surah Yunus: 94 (Jonah), the connotation of the verb " read" is not different from the previous ones except that it is followed by "the book", and here it is a religious text where the reading of it does not necessarily indicate the concept of uttering a written text, or changing the text written on a piece of paper into audible one.

\section{Second, a special concept of reading}

There are six verses where "read" occur in a special concept not familiar in pre-Islamic Arabic , and it is also different from what became agreed upon as in the Arabic of the Quran, where reading is related to the recitation of a sacred text. These three occurrences are in two verses of the Sura al-Alaq (the clot). (Read! In the Name of your Lord, Who has created (all that exist) Sura al-Alaq (the clot:1 ). , and (Read! And your Lord is the Most Generous) Sura alAlaq (the clot:3 ). , and this Sura is the first sura revealed to the Prophet . ${ }^{22}$, in addition to the verse (We shall make you to recite (the Qur'an), so you (O Muhammad) shall not forget (it),)(Sura al-Ala:6)

The three verses do not refer to the concept of reading from a paper.

And the three other verses are:

(Read your book. You yourself are sufficient as a reckoner against you this Day.) (Al-Isra: 14 ); So whosoever is given his record in his right hand, such will read their records, and they will not be dealt with unjustly in the least. (Al-Isra: 71). Then as for him who will be given his Record in his right hand will say: "Take, read my Record!Surah Al-Haqqah (The Inevitable).

These three verses where the verb "read" appear followed by the word "book" not from the divine books, but it is not a type of book that we used to know ; it is man's record of deeds when man in the day of questioning in the hereafter. However, there is no room to come up with different interpretation of the verb read except the meaning of the usual reading , though the book entity is not known, and that the way of reading is not realized it would appear to the researcher that the three verses are the foundation for a shift in the concept of reading from repeating the sacred text out in a loud or inaudible voice to looking at a paper and converting the symbols written on it to linguistics connotations the mind understands.

As for the verb " recite " (tala) which is written in Arabic in two different forms $(\square \mid \mathbb{I})$, it appears in the following Quranic contexts:

1. Narration of a story and news (And recite (O Muhammad) to them the story of him to whom We gave Our Ayat (proofs, evidences, verses, lessons, signs, revelations, etc.), but he threw them away, so Shaitan (Satan) followed him up, and he became of those who went astray.( Surah Al-A'raf (The Heights): 175)

2. revelation of Quranic verses on the messenger and then He recites them to people.

(And recite what has been revealed to you (O Muhammad) of the Book (the Qur'an) of your Lord (i.e. recite it, understand and follow its teachings and act on its orders and preach it to men). None can change His Words, and none will you find as a refuge other than Him.

(Surah Al-Kahf (The Cave): 27)

3. Explanation of Sharia provisions regarding the allowed and the prohibited acts ( Halal and Haram) (Say O Muhammad): "Come, I will recite what your Lord has prohibited you from: Join not anything in worship with Him; be good and dutiful to your parents; kill not your children because of poverty - We provide sustenance for you and for them; come not near to Al-Fawahish (shameful sins, illegal sexual intercourse, etc.) whether committed openly or secretly, and kill not anyone whom Allah has forbidden, except for a just cause (according to Islamic law). This He has commanded you that you may understand. Surah Al-An'am (The Cattle): 151)

4. correct reading with understanding and reflection (Those (who embraced Islam from Bani Israel) to whom We gave the Book [the Taurat (Torah)] [or those (Muhammad's Peace be upon him companions) to whom

\footnotetext{
${ }^{22}$ Noldke discusses this opinion and he states that the five first verses of Surah al-Alaq are the first verses in Qur'an ; see tarikh al-Qura'n , ibid P.96
} 
We have given the Book (the Qur'an)] recite it (i.e. obey its orders and follow its teachings) as it should be recited (i.e. followed), they are the ones that believe therein. And whoso disbelieves in it (the Qur'an), those are they who are the losers. (Surah Al-Baqarah (The Cow) 121; Tafsir Al-Qurtubi. Vol. 2, Page 95)

This is not exclusive to Qur'an as shown in the verse (All food was lawful to the Israeli people, except what Israel made unlawful for himself before the Taurat (Torah) was revealed. Say (O Muhammad(PBUH)): "Bring here the Taurat (Torah) and recite it, if you are truthful. "Surah Ale-Imran (The Family of Imran:93).

In differentiating between reading and recitation, The commentators talk about the following differences:

1- reading is assigned to the single word level and above, whereas reciting is assigned at the verse level and above.

2-recitation is a special kind of reading.

3- reading is for the Qur'an and what else, but the recitation shall be for the sacred religious text, and some people assigned recitation to Qur'an. Tahanawi says this that this restriction will restrict readers. ${ }^{23}$

4- tala (recited) often appears in verses, while read (qara') with the word Qura'n .Tala (recited) appears one time with Qura'n in the verse (And to recite the Qur'an, so whosoever receives guidance, receives it for the good of his ownself, and whosoever goes astray, say (to him): "I am only one of the warners. Surah An-Naml (The Ants:92)

5-in many verses read (qara') can be replaced by recited (tala) and subsequently the connotation does not change, and it should be noted that the Qur'an is well woven texts where no letter replaces another one.

6. Recited (tala) indicates repetition and recurrence, but this is not regular in all verses.

7-the word recited (tala) appears more than read ( ra') $^{\prime}$ in the Nobel Koran. Recite appears 62 times, in addition to one appearance that has nothing to do with the concept of reading in the verse (And by the sun and its brightness; And by the moon as it follows it (the sun) Surah Ash-Shams (The Sun: 1-2), whereas read (qara') appears 16 times, in addition to two occurrences in the form of gerund, currying the meaning of reading in the verse

( $\mathrm{t}$ is for Us to collect it and to give you (O Muhammad PBUH) the ability to recite it (the Qur'an):17). Qura'n as the name of the Book which was revealed to Muhammad (PBUH) appears 70 times.

8. recited associated with devils appears in the verse (They followed what the Shayatin (devils) gave out (falsely of the magic) in the lifetime of Sulaiman (Solomon). Sulaiman did not disbelieve, but the Shayatin (devils) disbelieved (Surah Al-Baqarah (The Cow:102)28 as opposed to (read). ${ }^{24}$

It is clear that the meanings provided by Arabic dictionaries for the verb "recited, recite ( tala, yatlu or tala yatli, two different forms in calligraphy) neither of which are related to the act of reading whose meaning is stored in the mind until today,

but the meaning provided in dictionaries at the end fof item is clearly a late after the revelation of the Qur'an, and this meaning started to be common in th tem is clearly a late after the revelation of the
fter the advent of Islam.
1-An'am: 105) (Thus We explain variously the
ooks of the people of the Scripture and brought
ople who have knowledge) and verse 156 in the
ent down to two sects before us (the Jews and
udied." Surah Al-An'am: 156)
verb "darasa"(studied), where the majority of
llama" (read and learnt ). It is a connotation

The verb "darasa "(studied ) appears in two verses, Verses so that they (the disbelievers) may say: "You $\mathrm{h}$ this Qur'an from that)" and that We may make the mat same Surah (Lest you (pagan Arabs) should say: "Th the Christians), and for our part, we were in fact unaw

Interpreters disagree with each other regarding the them link its connotation with the verbs "qara' and ta that does not agree with what is stated in poetry before Islam regarding the use of the verb " darasa" (studied) , where the meaning is associated with erasure, vanishing and absence of remains . However, al-Qurtubi provides interpretation of this verb according to the pronunciation ("darasat") by Ibn Amer, where all the three consonants are preannounced (da , ra, sat), Al-Qurtubi sade " The best thing that can be said about Ibn Amer reading is that the

${ }^{23}$ see Abu al-Baqa', al-Kuliyat, edited by Adnan Darwish and Mohammad al-Masri , Beirut , mu'assasat al-Risla 1998:, P. 226. and Al_tahanawi, kashf Mustalahat al-Olum wa al-Funoun, Beriut, Maktabat Lubnan :1996, 1/171

${ }^{24}$ There is a different aides in the interpretation of the ("tatlu alshayatin"), Some say talke and narrate, and talk about and tell, others say read like reciting Qur'an , and some follow and narrate and apply ; see al-Tabari , tafsir al-Tabari, Jami al-Bayan an Ta'weel al-Qur'an, edited by Bashshar ma'rouf and Husam al-harastani, Beirut, Mu'ssat al-Risaleh : 1994 , P. 315-316.

${ }^{25}$ Tafsir al-Tabari, 9/471-479, and al-Qurtubi , al-Jami li ahkam al-Qura'an, edited by Abdallah al-Turki and others , Beirut, Mu'ssat al-Risaleh :2006 , P. 8/489 and al-Nahas, I'rab al-Qur'an, edited Zuhair Zahid, Beirut, Alam al-Kutub wa dar al-Nahda :1985, P. $2 / 816$ 
meaning of "darasat"( vanished and erased) ${ }^{26}$ no remains left in the place where the trip lived ). This is consistent with the uses of the verb( darasa) ( (no remains left), whose connotation has developed later under the influence of the northern Semitic languages to become as used today, and it is linked with reading and learning, whereas and old reading has vanished and it is still exclusive to poetry until it became completely obsolete and hardly find we it in the Umayyad and Abbased poetry.

\section{6. (qara'a) in Semitic languages}

Semitic languages meet on common meanings of the words "qara', qiri" as in the following:

1. In the meaning of "called" or "called out loudly "in the Canaanite, and it is with glottal articulation of the vowel "a" (hamza), and in Hebrew, Aramaic, Syriac, and Nabatiese ${ }^{27}$. which means ( sawwata, or nada) in Arabic. It could be argued that the most semitic languages used this language item in this meaning except eloquent Arabic.

2- "qara" " in the meaning that we know about reading , that is the conversion of written symbols into audio material, whether silent or aloud. Appear in Canaanite, the oldest Semitic language where this meaning appears, and it seems that the Canaanite language writings which were found used the item to perform the two connotations, that is calling and calling out loudly ${ }^{28}$, whereas the Hebrew used this item like Arabic except that it kept the use of calling connotation in its uses ${ }^{29}$. In Thamudic, the word "qry" , In Punic $\left(q r^{\prime}\right)$ in Nabatia $\left(q r^{\prime}\right)$ in the meaning of (read) or named or shouted.$^{30}$

3. The only language that linked this $\operatorname{root}\left(\left(q r^{\prime}\right)\right.$ with sacred text is Aramaic and it seems that Syriac inherited this from it, as reflected in the Aramaic "qiryān" in the meaning of holy book, which is pronounc in Syriac with clear vowel "i" $i f t e r$ the letter "qaf" as in (qiryān, whereas Arabic favors the vowel "u" " am" as in "quryān" ${ }^{31}$, and the vowel developed and became "hamzeh" (glottal vowel \&) and the worlbecame " qur'an”.

4. South Arabian with its various dialects meet with Arabic before Islam in the connotation of " $q r^{\prime \prime}$ " in the meaning of commanded, or collected or gathered ${ }^{32}$, where this root does not indicate any connotation linked with the concept of reading like that which became agreed upon after the advent of Islam. From the above we can conclude that the common connotation of this root, which is the most common among Semitic languages, is that associated with calling or calling out loudly, and that the North Semitic languages, especially the Canaanite is where the connotation of this root developed to indicate reading in the meaning that became stable after the revelation of the Qur'an, and that Aramaic had linked between the concept of reading and that of the sacred text.

The researcher thinks that the root (qar'a) probably became horned in another root in Arabic after Islam, which is (talaya,talawa) ( recited, recitation ) to indicate the concept of reading before these became specialized in indicating a special type of reading which is the reading of the sacred text.

We can conclude an unambiguous result, that is, Semitic languages where the connotation of "qar' " had developed in this direction are languages of religious sacred text, namely Aramaic, Hebrew, and finally Arabic. This explains the absence of such connotation in South Semitic languages, although writing was common in them at a large scale. As writing entails reading, the absence of such connotation from the root 'read ' (qar') in southern Arabian language absolutely does not mean the absence of language indication for the act of reading.

It is noted that Bedouin dialects in the Levant and the Arabian Peninsula have unequivocally special indication to the connotation of "qar' " (read) in the Nobel Qur'an, whereas reading from a paper or something similar, they call it (decoding of calligraphy ), where people say ' $\mathrm{x}$ ' is unable to read/decode calligraphy, that is he is illiterate, and does not know how to read and write.

\footnotetext{
${ }^{26}$ Al-Qurtubi , al-Jami li ahkam al-Qura'an , edited by Abdallah al-Turki and others , Beirut, Mu'ssat al-Risaleh :2006, P. 8/489 and al-Nahas, I'rab al-Qur'an, edited Zuhair Zahid, Beirut, Alam al-Kutub wa dar al-Nahda :1985, P. 2/816

${ }^{27}$ Slouszch, P. 11, Tomback, P. 293, Hoftijzer \& Jongeling, PP. 1026-1027. Gesenius, P. 894. Costaz, P. 328 Cantineau, vol. II, PP. 143-144.

${ }^{28}$ Slouszch, P. 11, Tomback, P. 293, Hoftijzer \& Jongeling, PP. 1026-1027. Berthier \& Charlier, P. 94, Benz, P. 407, Tomback, P. 294

${ }^{29}$ Gesenius, P. 894.

${ }^{30}$ ( )Jaussen and Savignac, Mission Archeologique en Arabie, (Jsa). No. 724. Tomback, P. 293, Hoftijzer \& Jongeling, PP. 1026-1028, and Cantineau, vol. II, PP. 143-144.w

${ }^{31}$ Tomback, P. 294.

32 Beeston, P. 106.
} 


\section{References}

Beeston (et al). (1982). Sabaic Dictionary English-French-Arabic. Librairie du Liban, Beirut.

Benz, D. L. (1972). Personal Names in the Phoenician and Punic Inscriptions (Studia Bohl 8), Rome.

Berthier, Ch. (1952-1955). Le sanctuaire punique d'El-Hodra à Constantine.

Cantineau, E. (1978). Le Nabateen Notions Generales- Ecriture Grammaire, Otto Zeller, Osnabruck.

Christoph L. (2007). The Syro-Aramaic Reading of the Koran (German edition 2000, English translation 2007)

Costaz, C.J. (2002). Syriac-French-English-Arabic-Dictionary, Dar Al mashriq , Bayrut .

Gesenius, X. (1979). A Hebrew and English Lexicon of the Old Testament, Translated by: Brown, Driver, and Briggs, Clarindon Press, Oxford.

Gesenius, R. (1978). Hebrew and Chaldee Lexicon of the Old Testament, Edited by; Samuel Prideaux Tregelles, Michigan.

Tomback, R. (1978). A Comparative Semitic Lexicon of the Phoenician and Punic Languages, USA, Slouszch, N.(1942). Otzar Hakkitobot Happiniqiyot.Thesaurus of Phoenician Inscriptions.

Theodor, N. (2013). Friedrich Schwally, Gotthelf Bergsträßer and Otto Pretzl. Edited and translated by Wolfgang H. Behn, The History of the Qur'ān, Linden- Boston.

\section{Arabic references}

Abu A.B. (1998). al-Kuliyat, Adnan Darwish, Mohammed al-Masri eds. , Beirut, mu'ssat al-Risaleh .

Abu Obeida, D., Muammar, M. (N.D), majaz al-Qur'an, , Mohammad Sezkin ed. , Cairo, Khanji Library.

Al’Asha,( Diwan) (N.D) Mohammad Hussein ed. ,Cairo, Maktabat al_Adab in Jamamiz .

Al-huzliyyin, (Diwan) (1995). Ahmed Zein, Cairo, Dar al-Kutub al_masria, .

Al-Bukhari,(2002). Sahih al-Bukhari, $\quad$ Beirut, Dar $\quad$ Ibn Kathir Al-Fakher al-Razi. (1981). Mafateeh al-Ghaib (tafsir al-Razi) Beirut, Dar al-Fiker.

Al-Raghib al- Asfahani. (2009). mufradat alfad al-Qur'an, edited by Safwan Adnan Daoudi, Damascus, Dar al-Qalam

Al-Tahanawi. (1996). Kashaf Mustalhat al-Aloum and al-Funoun , Beirut, maktabat Lubnan .

Amr Ibn Kulthum,(Diwan). (1991). Amer Bin Kalthoum Collection of poetry, Emile Badie yaqoub, ed. , Beirut, Dar al-Kitab al-Arabi

Ibn al-Athir. (1979), al-Nihaya fi Gharib al-Hadith and al-Athar, Ahmed Zaoui and Mahmoud Tunahi eds. , Beirut, alMaktaba al-Ilmia

Iben Miqbel. (Diwan) (1995). Azza Hassan ed , Beirut, Dar al-Sharq al-Arabi .

Ibn faris. (2002). Maqaees al_Lugha, Haroon Abdul Salam ed., Damascus, Arab Writers Union.

Ibn Mandour(N.D) Lisan al-Arab , Beirut, Dar Sader.

Jawad, A. (1993). al-Mufassal in the history of the Arabs before Islam, Baghdad, Baghdad University:

Mohammad Abed al-Jabri,(2006) the illiterate Prophet and the nation's illiteracy - Al Ittihad newspaper Emirates On:9\4\2006

Mohammad, A.A. (1999) al-Wkouf ala al-Omiah end Arab al-Jahilia, Cairo, Markaz z alhadara alarabia.

Mohammad Sh. (2010). Alkitab wa Alquran,qirah muasirah,Beirut, Dar al-Saqi. Nasir al-Din A.A. (1988). pre-Islamic poetry sources, Cairo, Dar al-Ma'arif .

Nasr Hamed Abu Zeid (1990), Mafhoum al-Nass, Dirasat fi Aloum al-Qur'an, al-Hai'al-Masria al-Alameyyah lelkitab. Mahmoud, A.D. (2011). words of writing in pre-Islamic poetry, Majalat al-Adab , Algeria , Université des Frère Mentouri Constantine.

Tabari, G. (1994). Tafsir Al-Tabari, jami’ al-bayan an ta'weel al-Qura'n , Bashar Marouf and Hossam al-Harstani, Beirut, Mu'ssat al-Risaleh. 